\title{
Protein and energy relations in the broiler chicken
}

\author{
Chronic or acute effects of alternating protein or intermittent feeding regimens on \\ broiler lipid metabolism*
}

\author{
By R. W. ROSEBROUGH, J. P. MCMURTRY AND N. C. STEELE \\ Nonruminant Animal Nutrition Laboratory, Livestock and Poultry Sciences Institute, \\ United States Department of Agriculture, Agricultural Research Service, Beltsville \\ Agricultural Research Center, Beltsville, MD 20705, USA
}

(Received 22 December 1987 - Accepted 4 November 1988)

1. Broiler chickens growing from 7 to $28 \mathrm{~d}$ of age were given: (1) a $210 \mathrm{~g}$ protein $/ \mathrm{kg}$ control diet for the entire experimental period, (2) an intermittent feeding regimen $(210 \mathrm{~g}$ protein $/ \mathrm{kg}$ diet for either 1 or $2 \mathrm{~d}$ followed by a $1 \mathrm{~d}$ fast), or (3) a daily change in the dietary protein level from 120 to $300 \mathrm{~g} / \mathrm{kg}$ diet. Treatment variables examined were lipogenesis and glucose production in vitro, and circulating concentrations of insulin, triiodothyronine $\left(\mathrm{T}_{3}\right)$ and thyroxine $\left(\mathrm{T}_{4}\right)$ to determine the effects of chronic or acute dietary treatments.

2. Giving the $300 \mathrm{~g}$ protein $/ \mathrm{kg}$ diet or withholding feed for $1 \mathrm{~d}$ decreased $(P<0.05)$ lipogenesis in vitro compared with controls.

3. Giving the $120 \mathrm{~g}$ protein $/ \mathrm{kg}$ diet or refeeding with a $210 \mathrm{~g}$ protein $/ \mathrm{kg}$ diet for 1 or $2 \mathrm{~d}$ increased $(P<0.05)$ lipogenesis in vitro compared with controls. Glucose production was affected in the same manner.

4. Fasting decreased $(P<0.05)$ plasma insulin and $\mathrm{T}_{3}$ and increased $\mathrm{T}_{4}$. Both refeeding and a low-protein diet increased $\mathrm{T}_{3}$. Refeeding increased and a low-protein diet decreased insulin.

5. Chronic use (7-28 d of age) of either an alternating protein or intermittent feeding regimen caused greater responses compared with acute bouts (single cycle) of either of the regimens.

There are findings characterizing physiological responses to meal feeding and intermittent feeding in rodents. Both these feeding regimens increase lipogenesis de novo, carcass and liver fat, and improve dietary energy utilization. Early reports (Leveille, 1966; Yeh \& Leveille, 1971) showed that periodic feeding regimens increase lipid metabolism in vitro in chickens but do not improve energetic efficiency. We found that intermittent feeding cycles or daily changes in the dietary protein level also change lipid metabolism (Rosebrough \& Steele, 1985). The alteration in metabolism is similar to the intermittent feeding response noted in older chickens (Leveille \& Yeh, 1972).

An overall comparison between the effects of diet composition and feeding regimens reveals that giving low-protein diets as a part of an alternating high-low-protein feeding cycle and refeeding fasted chickens result in similar responses. In both cases, lipid synthesis de novo increases. In contrast, giving high-protein diets and feeding fasting chickens decrease lipogenesis de novo. It is of interest if both these types of nutritional regimens can be used on a chronic basis to adapt intermediary metabolism in the broiler to increase lipogenesis further during the respective refeeding and low-protein phases of the two feeding programmes.

The purpose of the present study was to examine lipogenesis and glucose production in vitro in chickens subjected to chronic or acute bouts of either an intermittent or alternating protein feeding regimen. The overall hypothesis was that an alternating protein diet series would result in a metabolic response similar to the refeeding response noted during the intermittent feeding regimen. Circulating metabolic hormone levels were also measured

\footnotetext{
* Mention of a trade name, proprietary product or vendor does not constitute a guarantee or warranty of the product by USDA or imply its approval to the exclusion of other suitable products or vendors.
} 
during chronic and acute dietary treatment regimens. We were especially interested in the adaptations made by chickens subjected to repeated bouts of high-low-protein feeding and fasting-refeeding, compared with those made by chickens subjected to single bouts of these two regimens.

\section{MATERIALS AND METHODS}

Animals. Male broiler chickens (Ross) were purchased from ISA Poultry Services, Gainesville, GA. Chickens were fed on a common starter diet $(230 \mathrm{~g}$ crude protein (nitrogen $\times 6.25$ ) and $13 \mathrm{MJ}$ metabolizable energy $/ \mathrm{kg}$ ) to $7 \mathrm{~d}$ of age and then randomly assigned to dietary treatment groups. Experiments were planned with these chickens (average weight $160 \mathrm{~g}$ ) to determine the effects of chronic or acute bouts of either intermittent feeding or cyclic levels of dietary protein on metabolism in broiler chickens. Chickens were raised in Petersime chick batteries in an environmentally controlled room maintained at $22^{\circ}$, and given their respective diets until the termination of the experiment. A $12 \mathrm{~h}$ light $-12 \mathrm{~h}$ dark cycle (06.00-18.00 hours light) was maintained, and water was available ad lib.

Diets and feeding regimens. Three diets were formulated to contain 120,210 and $300 \mathrm{~g}$ crude protein and approximately $13 \mathrm{MJ}$ metabolizable energy $/ \mathrm{kg}$. In addition, the diets were also formulated to contain $68-70 \%$ of the total energy as carbohydrate. This was accomplished by the energy contribution for fat and protein and assuming the remainder to be carbohydrate. Maize starch was assumed to be $100 \%$ carbohydrate energy and isolated soya-bean protein was assumed to be carbohydrate-free. The differences in energy from fat among the diets were considered to be insignificant because the greatest contribution from fat $(<5 \%)$ to dietary energy was in the $120 \mathrm{~g}$ crude protein $/ \mathrm{kg}$ diet. This level of fat energy probably does not affect intermediary metabolism (Hillard et al. 1980). The diets are shown in Table 1.

For the first experiment, 192 chickens were placed in three battery brooders (eight chickens per pen and eight pens per brooder) and assigned to one of three dietary treatments (eight pen replicates per dietary treatment). Replicates were arranged as blocks within batteries with all treatments appearing at a particular tier level among batteries. Previous research in our laboratory has established a slight effect of pen height. In contrast we cannot show variation among batteries so this factor was discounted as a source of variation. The first treatment was a $3 \mathrm{~d}$ intermittent feeding regimen ( $1 \mathrm{~d}$ fast- $2 \mathrm{~d}$ refeed). The second treatment was a daily alternating dietary protein regimen $(120 \mathrm{~g}$ protein $/ \mathrm{kg}$ on day 1 and $300 \mathrm{~g}$ protein $/ \mathrm{kg}$ on day 2). The control treatment was a $210 \mathrm{~g}$ protein $/ \mathrm{kg}$ diet for the entire $21 \mathrm{~d}$ experimental period. These cycles were repeated until the chickens were $28 \mathrm{~d}$ of age. Chickens fed on the control diet were also placed on either the first or second treatment for one cycle to determine acute treatment effects. On day 28 and on successive days, two chickens were selected from each pen replicate at 09.00 hours to minimize diurnal variation. Chickens were bled by cardiac puncture into combination syringe-collection tubes containing EDTA as an anticoagulant (Sarstedt Corp., Princeton, NJ). The blood samples were centrifuged at $600 \times \mathrm{g}$. Plasma samples were collected with individual Pasteur pipettes and were stored at $-70^{\circ}$ for later analyses of metabolic hormones. The chickens were then weighted and killed by cervical dislocation. The livers were weighed and placed in individual vessels containing $10 \mathrm{~mm}$-HEPES $\left(N\right.$-2-hydroxyethyl piperazine- $N^{\prime}$-2-ethane sulphonic acid) and 155 mm-sodium chloride (pH 7.5).

Expt 2 was similar to the first experiment although the intermittent feeding regimen was modified to a $1 \mathrm{~d}$ fast followed by a $1 \mathrm{~d}$ refeed. In addition, assays in vitro were expanded to include an estimate of net glucose production by liver explants. Plasma insulin, 
Table 1. Composition $(\mathrm{g} / \mathrm{kg}$ diet $)$ of the diets

\begin{tabular}{|c|c|c|c|}
\hline \multirow[b]{2}{*}{ Ingredient } & \multicolumn{3}{|c|}{ Dietary crude protein (nitrogen $\times 6 \cdot 25)(\mathrm{g} / \mathrm{kg})$} \\
\hline & 120 & 210 & 300 \\
\hline Maize meal & 800 & 600 & 400 \\
\hline Soya-bean meal $(490 \mathrm{~g}$ protein $/ \mathrm{kg})$ & 100 & 50 & \\
\hline Soya-bean protein ${ }^{*}$ & & 150 & 300 \\
\hline Maize starch & 40 & 140 & 240 \\
\hline Dicalcium phosphate & 40 & 40 & 40 \\
\hline Limestone & 10 & 10 & 10 \\
\hline Selenium premix $\dagger$ & 1 & & \\
\hline Mineral premix $\ddagger$ & 1 & 1 & 1 \\
\hline Vitamin premix $\S$ & 5 & 5 & 5 \\
\hline Iodized salt & 3 & 3 & 3 \\
\hline \multicolumn{4}{|l|}{ Calculated analyses } \\
\hline Metabolizable energy $(\mathrm{MJ} / \mathrm{kg})$ & $12 \cdot 9$ & $13 \cdot 2$ & $13 \cdot 0$ \\
\hline Carbohydrate $(\mathrm{MJ} / \mathrm{kg})$ & 9.7 & $9 \cdot 3$ & 8.9 \\
\hline
\end{tabular}

* Soya-bean protein grade II (21726), US Biochemicals, PO Box 22400, Cleveland, Ohio 44122

$\dagger$ Provided $0.2 \mathrm{mg} \mathrm{Se} / \mathrm{kg}$ diet.

$\ddagger$ Provided (mg/kg diet): manganese 100 , iron 100 , copper 10 , cobalt 1 , iodine 1 , zinc 100 , calcium 89 .

$\S$ Provided (mg/ $\mathrm{kg}$ diet): retinol 36 , cholecalciferol $75 \mu \mathrm{g}$, vitamin E 100 , riboflavin 10, pantothenic acid 20 , choline $2 \mathrm{~g}$, niacin 100 , thiamin 10 , vitamin $\mathrm{B}_{\mathrm{B}} 10$, menadione sodium bisulphite $1 \cdot 5$, vitamin $\mathrm{B}_{12} 100 \mu \mathrm{g}$, folic acid 2 , ethoxyquin 150 .

triiodothyronine $\left(\mathrm{T}_{3}\right)$ and thyroxine $\left(\mathrm{T}_{4}\right)$ concentrations were also measured during chronic and acute dietary treatments.

Enzyme activities. A portion of each liver was homogenized in $50 \mathrm{~mm}$-HEPES-3.3 mMmercaptoethanol (pH 7.5) and centrifuged for $60 \mathrm{~min}$ at $50000 \times \mathrm{g}$. The supernatant fraction was stored frozen $\left(-80^{\circ}\right)$ until the activities of malate dehydrogenase (oxaloacetate-decarboxylating) $\left(\mathrm{NADP}^{+}\right)$(malic enzyme) (EC 1.1.1.40, ME; Hsu \& Lardy, 1969), isocitrate dehydrogenase $\left(\mathrm{NADP}^{+}\right)(E C$ 1.1.1.42, ICD; Cleland et al. 1969) and fatty acid synthase (EC 2.3.1.85, FAS; Mersmann et al. 1973) were measured. Activities are expressed as $\mu \mathrm{mol}$ of product formed $/ \mathrm{min}$ under the assay conditions (Rosebrough \& Steele, 1985).

Lipogenesis. Another portion of each liver was then sliced (50-75 mg explants) with a Stadie-Riggs hand microtome. Duplicate explants were incubated at $37^{\circ}$ for $2 \mathrm{~h}$ in Hanks' balanced salts (HBSS; Hanks \& Wallace, 1949) supplemented with 10 mM-HEPES, bovine serum albumin $(10 \mathrm{~g} / \mathrm{l})$ and $20 \mathrm{~mm}$-sodium[2- $\left.{ }^{14} \mathrm{C}\right]$ acetate $(37$ disintegrations/min per $\mathrm{nmol}$ ). After $2 \mathrm{~h}$, the slices were extracted and treated according to Folch et al. (1957). Lipogenesis was noted as that amount of sodium $\left[2-{ }^{14} \mathrm{C}\right]$ acetate incorporated into hepatic fatty acids during the incubation period. This value is expressed per $\mathrm{g}$ liver and per $\mathrm{kg}$ body-weight.

Glucose production. Duplicate slices were also incubated at $37^{\circ}$ for $2 \mathrm{~h}$ in HBSS supplemented with $10 \mathrm{~mm}$-HEPES and bovine serum albumin $(10 \mathrm{~g} / 1)$ in the presence and absence of $10 \mathrm{~mm}$-pyruvate. Glucose was then measured in the medium with a coupled hexokinase $(E C$ 2.7.1.1) + glucose-6-phosphate dehydrogenase $(E C$ 1.1.1.49) reaction (Stein, 1963).

Plasma metabolites. Plasma insulin concentration was estimated with a homologous avian radioimmunoassay system which uses chicken insulin as both the standard and ${ }^{125}$ I-labelled tracer. The primary antiserum has been described previously (McMurtry et al. 
Table 2. Expt 1. Effect of intermittent feeding ( 1 d fast-2 d refeed) or alternating protein feeding (120 $\mathrm{g}$ protein $/ \mathrm{kg}$ on day 1 and $300 \mathrm{~g}$ protein $/ \mathrm{kg}$ on day 2) regimens on chicken growth from 7 to $28 d$ of age*

(Mean values with their standard errors for eight pens per dietary treatment)

\begin{tabular}{|c|c|c|c|c|c|}
\hline \multirow[b]{2}{*}{ Diet, days $7-28$} & \multicolumn{2}{|c|}{$28-d$ wt $(g)$} & \multicolumn{2}{|c|}{ Food intake (g) } & \multirow{2}{*}{$\begin{array}{c}\text { Food } \\
\text { conversion } \\
\text { efficiency }\end{array}$} \\
\hline & Mean & SE & Mean & SE & \\
\hline Control & 1137 & $15^{\mathrm{c}}$ & 1753 & $19^{c}$ & 0.574 \\
\hline Intermittent feeding: & 932 & $16^{\mathrm{a}}$ & 1437 & $9^{a}$ & 0.558 \\
\hline Alternating protein: & 1072 & $18^{\mathrm{b}}$ & 1638 & $17^{b}$ & 0.592 \\
\hline $120 \mathrm{~g} / \mathrm{kg}$ & & & 860 & 9 & \\
\hline $300 \mathrm{~g} / \mathrm{kg}$ & & & 778 & 8 & \\
\hline
\end{tabular}

a, b, e Values within a vertical column with different superscript letters were significantly different $(P<0.05)$.

* Chickens (7-d-old; average wt $160 \mathrm{~g}$ ) were assigned to these dietary treatments : (1) control ( $210 \mathrm{~g}$ protein $/ \mathrm{kg}$ diet for the entire experimental period), (2) intermittent feeding ( $210 \mathrm{~g}$ protein $/ \mathrm{kg}$ diet for $2 \mathrm{~d}$ followed by a $1 \mathrm{~d}$ fast) or (3) a daily alternating dietary protein regimen $(120 \mathrm{~g}$ protein $/ \mathrm{kg}$ on day 1 and $300 \mathrm{~g} \mathrm{protein} / \mathrm{kg}$ on day 2). These cycles were continued for $20 \mathrm{~d}$ and then chickens were selected from each treatment to determine the effects of dietary treatments on intermediary metabolism.

1983). Both $T_{3}$ and $T_{4}$ concentrations were estimated with commercial, solid-phase kits (Immuchem Corp, Carson, CA). These assays were validated for avian samples by dispersing standards in charcoal-stripped chicken serums and by noting recovery of added $\mathrm{T}_{3}$ and $\mathrm{T}_{4}(94 \%)$. All hormone assays were conducted as single batches to minimize intraassay variation. The inter-assay coefficients of variation averaged 2.7 and $1.3 \%$ for $T_{3}$ and $\mathrm{T}_{4}$ respectively.

Statistical analyses. Metabolic activities are expressed per $\mathrm{g}$ of liver and per unit relative liver size (liver as percentage of body-weight $\times$ metabolic activity per $g$ liver). The values for chickens from a particular pen were averaged to derive a pen mean which was considered as the experimental unit. Values were analysed as a randomized block design with tier position pooled across batteries as the blocking factor. Significance of differences between control and experimental treatment means was tested with Student's $t$ test at the 0.05 level of probability (Remington \& Schork, 1970).

\section{RESULTS}

Expt 1. Body-weights and feed consumption are presented in Table 2. Chickens fed on an intermittent basis were lighter $(P<0.05)$ than chickens fed on the alternating protein diets. Both these two groups were lighter $(P<0.05)$ than controls (given a diet containing $210 \mathrm{~g} / \mathrm{kg}$ protein diet throughout the $21-\mathrm{d}$ experimental period). Voluntary feed intake for both of these groups was also less $(P<0.05)$ than that for controls. We also found that chickens fed on the alternating protein diets ate more of the diet containing $120 \mathrm{~g}$ protein/ $\mathrm{kg}$ than of the diet containing $300 \mathrm{~g}$ protein $/ \mathrm{kg}$.

Values relating to the effect of intermittent feeding and alternating protein regimens on lipogenesis are presented in Table 3. Values shown are expressed on a $\mathrm{g}$ liver and a kg bodyweight basis to estimate whole-body lipogenic potential. When compared with values for controls, the $1 \mathrm{~d}$ fast decreased $(P<0.05)$ lipogenesis in chickens; however, refeeding these same chickens increased $(P<0.05)$ lipogenesis $100 \%$ relative to controls on both days of refeeding. A single fast-refeed bout also gave similar results although the size of the 
Table 3. Expt 1. Effect of intermittent feeding ( 1 d fast $-2 d$ refeed) or alternating protein feeding ( $120 \mathrm{~g}$ protein $/ \mathrm{kg}$ on day 1 and $300 \mathrm{~g}$ protein $/ \mathrm{kg}$ on day 2) regimens on lipogenesis in vitro $\left(\left[2-{ }^{14}\right.\right.$ C]acetate incorporation into hepatic fatty acids) by liver explants from broiler chickens $\dagger$

(Mean values with their standard errors for four pens per dietary treatment)

\begin{tabular}{|c|c|c|c|c|c|}
\hline & & \multicolumn{2}{|c|}{ Cycled days $7-28 \dagger$} & \multicolumn{2}{|c|}{ Control days 7-28t } \\
\hline & & Mean & $\mathrm{SE}$ & Mean & $\mathrm{SE}$ \\
\hline \multicolumn{6}{|l|}{$\mu \mathrm{mol} / \mathrm{g}$ liver: } \\
\hline Control & & $25 \cdot 1$ & $2 \cdot 3$ & $25 \cdot 1$ & $2 \cdot 3$ \\
\hline \multirow[t]{3}{*}{ Intermittent feeding: } & Fed Id & $53 \cdot 3^{3 *}$ & $2 \cdot 8$ & $35 \cdot 0^{6 *}$ & $2 \cdot 8$ \\
\hline & Fed $2 d$ & $64 \cdot 6^{\text {a* }}$ & 1.6 & $28 \cdot 9^{\mathrm{b} *}$ & $4 \cdot 1$ \\
\hline & Fasted $1 \mathrm{~d}$ & $3 \cdot 0^{\mathrm{a} *}$ & 0.2 & $1 \cdot 7^{\mathrm{b*}}$ & $0 \cdot 1$ \\
\hline \multirow[t]{2}{*}{ Alternating protein: } & $120 \mathrm{~g} / \mathrm{kg}$ & $51 \cdot 8^{a *}$ & $1 \cdot 7$ & $42 \cdot 3^{b *}$ & $2 \cdot 4$ \\
\hline & $300 \mathrm{~g} / \mathrm{kg}$ & $21 \cdot 9^{\mathrm{a} *}$ & $2 \cdot 3$ & $28 \cdot 1^{\mathrm{b} *}$ & $1 \cdot 2$ \\
\hline \multicolumn{6}{|l|}{$\mu \mathrm{mol} / \mathrm{kg}$ body-wt: } \\
\hline Control & & 510 & 50 & 510 & 50 \\
\hline \multirow[t]{3}{*}{ Intermittent feeding: } & Fed $1 \mathrm{~d}$ & $1830^{\mathrm{a} *}$ & 110 & $1060^{6 *}$ & 11 \\
\hline & Fed $2 d$ & $2260^{\mathrm{a} *}$ & 90 & $760^{\mathrm{b} *}$ & 110 \\
\hline & Fasted $1 \mathrm{~d}$ & $60^{*}$ & 10 & $30^{*}$ & 10 \\
\hline \multirow[t]{2}{*}{ Alternating protein: } & $120 \mathrm{~g} / \mathrm{kg}$ & $1480^{\mathrm{a} *}$ & 80 & $1160^{\mathrm{b} *}$ & 80 \\
\hline & $300 \mathrm{~g} / \mathrm{kg}$ & $920^{\mathrm{a} *}$ & 50 & $690^{\mathrm{b} *}$ & 40 \\
\hline
\end{tabular}

a, b Values within a horizontal row with unlike superscript letters were significantly different $(P<0.05)$.

* Mean value was significantly different from control value $(P<0.05)$.

$\dagger$ Chickens ( 7 -d-old; average wt $160 \mathrm{~g}$ ) were assigned to these dietary treatments: (1) control $(210 \mathrm{~g} \mathrm{protein} / \mathrm{kg}$ diet for the entire experimental period), (2) intermittent feeding ( $210 \mathrm{~g}$ protein $/ \mathrm{kg}$ diet for $2 \mathrm{~d}$ followed by a $1 \mathrm{~d}$ fast) or (3) a daily alternating dietary protein regimen $(120 \mathrm{~g}$ protein $/ \mathrm{kg}$ on day 1 and $300 \mathrm{~g}$ protein $/ \mathrm{kg}$ on day 2). These cycles were continued for $20 \mathrm{~d}$ and then chickens were selected from each treatment to determine the effects of dietary treatments on intermediary metabolism.

$\ddagger$ Pens of controls were subjected to a single intermittent feeding or alternating protein feeding.

response was not nearly as great. A comparison between chronic and acute treatment groups showed that the rebound in lipogenesis was greater $(P<0.05)$ in the chronic than in the acute treatment group. Switching from 300 to $120 \mathrm{~g}$ protein $/ \mathrm{kg}$ diet also increased lipogenesis in both the chronic and acute treatment groups, although the increase did not approach that noted by refeeding.

Expt 2. This experiment was designed to explore further extremes in metabolism caused by a $1 \mathrm{~d}$ on- $1 \mathrm{~d}$ off intermittent feeding regimen compared with the alternating protein regimen. The $1 \mathrm{~d}$ on-1 d off regimen was chosen because the regimen involved a $2 \mathrm{~d}$ cycle like the alternating protein regimen. Chickens fed on the control diet were heavier $(P<0.05)$ than those in either of the two experimental groups (Table 4). The chickens fed on the alternating protein regimen were heavier $(P<0.05)$ than chickens fed on an intermittent basis. There were no significant differences in gain per unit feed intake.

The alternating protein regimen, either on an acute or chronic basis, resulted in patterns of lipogenesis similar to those in Expt 1 (Table 5). Shortening the intermittent feeding regimen accentuated the previously noted rebound in lipogenesis following refeeding. The chronic treatment increased lipogenesis following refeeding; moreover, the response was nearly twice that of the acute treatment group.

The chronic, intermittent feeding regimen lowered $(P<0.05)$ net glucose production on both days of the cycle compared with the respective controls (Table 6). The diet containing $300 \mathrm{~g}$ progein $/ \mathrm{kg}$, as a component of the alternating protein regimen, also lowered 
Table 4. Expt. 2. Effect of intermittent feeding ( $1 d$ fast-1 d refeed) or alternating protein feeding ( $120 \mathrm{~g}$ protein $/ \mathrm{kg}$ on day $\mathrm{l}$ and $300 \mathrm{~g}$ protein $/ \mathrm{kg}$ on day 2) regimens on chicken growth from 7 to 28 d of age*

(Mean values with their standard errors for eight pens per dietary treatment)

\begin{tabular}{lcccccc}
\hline & \multicolumn{2}{c}{$28-\mathrm{d}$ wt $(\mathrm{g})$} & & \multicolumn{2}{c}{ Food intake $(\mathrm{g})$} & $\begin{array}{c}\text { Food } \\
\text { conversion } \\
\text { efficiency }\end{array}$ \\
\cline { 2 - 3 } \cline { 5 - 6 } Diet, days $7-28$ & Mean & SE & & Mean & SE & \\
\hline Control & $1072^{\mathrm{c}}$ & 9 & $1508^{\mathrm{b}}$ & 19 & 0.625 \\
Intermittent feeding & $621^{\mathrm{a}}$ & 5 & & $791^{\mathrm{a}}$ & 38 & 0.625 \\
Alternating protein: & $971^{\mathrm{b}}$ & 9 & $1426^{\mathrm{b}}$ & 33 & 0.592 \\
$120 \mathrm{~g} / \mathrm{kg}$ & & & 746 & 21 & \\
$300 \mathrm{~g} / \mathrm{kg}$ & & & 680 & 13 & \\
\hline
\end{tabular}

a, b.c. Values within a vertical column with different superscript letters were significantly different $(P<0.05)$.

* Chickens (7-d-old ; average wt $160 \mathrm{~g}$ ) were assigned to these dietary treatments: (1) control $(210 \mathrm{~g}$ protein $/ \mathrm{kg}$ diet for the entire experimental period), (2) intermittent feeding ( $210 \mathrm{~g}$ protein $/ \mathrm{kg}$ diet for $1 \mathrm{~d}$ followed by a $1 \mathrm{~d}$ fast) or (3) a daily alternating dietary protein regimen $(120 \mathrm{~g}$ protein $/ \mathrm{kg}$ on day 1 and $300 \mathrm{~g}$ protein $/ \mathrm{kg}$ on day 2). These cycles were continued for $20 \mathrm{~d}$ and then chickens were selected from each treatment to determine the effects of dietary treatments on intermediary metabolism.

Table 5. Expt 2. Effect of intermittent feeding (1 d fast-1 d refeed) or alternating protein feeding ( $120 \mathrm{~g}$ protein $/ \mathrm{kg}$ on day 1 and $300 \mathrm{~g}$ protein $/ \mathrm{kg}$ on day 2) regimens on lipogenesis in vitro $\left(\left[2-{ }^{14}\right.\right.$ C]acetate incorporation into hepatic fatty acids) by liver explants from broiler chickens $\dagger$

(Mean values with their standard errors for four pens per dietary treatment)

\begin{tabular}{|c|c|c|c|c|c|}
\hline & & \multicolumn{2}{|c|}{ Cycled days $7-28 \dagger$} & \multicolumn{2}{|c|}{ Control days $7-28 \ddagger$} \\
\hline & & Mean & SE & Mean & $\mathrm{SE}$ \\
\hline \multicolumn{6}{|l|}{$\mu \mathrm{mol} / \mathrm{g}$ liver: } \\
\hline Control & & $13 \cdot 6$ & $1 \cdot 8$ & $13 \cdot 6$ & $1 \cdot 8$ \\
\hline \multirow[t]{2}{*}{ Intermittent feeding: } & Fed Id & $79 \cdot 6^{\mathrm{a} *}$ & $5 \cdot 0$ & $33 \cdot 4^{\mathrm{b} *}$ & $7 \cdot 5$ \\
\hline & Fasted $1 \mathrm{~d}$ & $3 \cdot 6^{\text {a* }}$ & 0.5 & $1 \cdot 7^{\mathrm{b} *}$ & $0 \cdot 1$ \\
\hline \multirow[t]{2}{*}{ Alternating protein: } & $120 \mathrm{~g} / \mathrm{kg}$ & $66 \cdot 4^{\mathrm{a} *}$ & $8 \cdot 1$ & $49 \cdot 0^{\mathrm{b} *}$ & $5 \cdot 3$ \\
\hline & $300 \mathrm{~g} / \mathrm{kg}$ & $25 \cdot 0^{\mathrm{a} *}$ & $5 \cdot 2$ & $16 \cdot 4^{b *}$ & $2 \cdot 1$ \\
\hline \multicolumn{6}{|l|}{$\mu \mathrm{mol} / \mathrm{kg}$ body-wt: } \\
\hline Control & & $290 \cdot 0$ & $40 \cdot 0$ & $290 \cdot 0$ & $40 \cdot 0$ \\
\hline \multirow[t]{2}{*}{ Intermittent feeding: } & Fed I d & $2500 \cdot 0^{\mathrm{a} *}$ & $160 \cdot 0$ & $1002 \cdot 0^{\mathrm{b} *}$ & $180-0$ \\
\hline & Fasted $1 \mathrm{~d}$ & $80 \cdot 0^{*}$ & $14 \cdot 0$ & $90 \cdot 0^{*}$ & $10^{-0} 0$ \\
\hline \multirow[t]{2}{*}{ Alternating protein: } & $120 \mathrm{~g} / \mathrm{kg}$ & $1760 \cdot 0^{a *}$ & $223 \cdot 0$ & $1206 \cdot 0^{5 *}$ & $130 \cdot 0$ \\
\hline & $300 \mathrm{~g} / \mathrm{kg}$ & $580 \cdot 0^{\mathrm{a} *}$ & $121 \cdot 0$ & $439 \cdot 0^{\mathrm{b} *}$ & $50 \cdot 0$ \\
\hline
\end{tabular}

a, b Values within a horizontal row with unlike superscript letters were significantly different $(P<0 \cdot 05)$.

* Mean value was significantly different from control value $(P<0.05)$.

$\dagger$ Chickens (7-d-old; average wt $160 \mathrm{~g}$ ) were assigned to these dietary treatments: (1) control (210 g protein/ $\mathrm{kg}$ diet for the entire experimental period), (2) intermittent feeding $(210 \mathrm{~g}$ protein $/ \mathrm{kg}$ diet for $1 \mathrm{~d}$ followed by a $1 \mathrm{~d}$ fast) or (3) a daily alternating dietary protein regimen $(120 \mathrm{~g} / \mathrm{kg}$ protein on day 1 and $300 \mathrm{~g} / \mathrm{kg}$ protein on day 2). These cycles were continued for $20 \mathrm{~d}$ and then chickens were selected from each treatment to determine the effects of dietary treatments on intermediary metabolism.

$\ddagger$ Pens of controls were subjected to a single intermittent feeding or alternating protein feeding. 
Table 6. Expt. 2. Effect of intermittent feeding ( 1 d fast -1 d refeed) or alternating protein feeding ( $120 \mathrm{~g}$ protein $/ \mathrm{kg}$ on day 1 and $300 \mathrm{~g}$ protein $/ \mathrm{kg}$ on day 2) regimens on glucose production (glucose produced in the presence of pyruvate) by liver explants from broiler chickens $\dagger$

(Mean values with their standard errors for four pens per dietary treatment)

\begin{tabular}{|c|c|c|c|c|c|}
\hline & & \multicolumn{2}{|c|}{ Cycled days $7-28 \dagger$} & \multicolumn{2}{|c|}{ Control days $7-28 \ddagger$} \\
\hline & & Mean & SE & Mean & SE \\
\hline \multicolumn{6}{|l|}{$\mu \mathrm{mol} / \mathrm{g}$ liver: } \\
\hline Control & & $156 \cdot 0$ & $11 \cdot 7$ & $156 \cdot 0$ & $11 \cdot 7$ \\
\hline \multirow[t]{2}{*}{ Intermittent feeding: } & Fed $1 \mathrm{~d}$ & $89 \cdot 4^{a \star}$ & $5 \cdot 6^{\mathrm{a}}$ & $138 \cdot 4^{\mathrm{b}}$ & $10 \cdot 2$ \\
\hline & Fasted $1 \mathrm{~d}$ & $15 \cdot 7^{*}$ & $0 \cdot 81^{\mathrm{a}}$ & $18 \cdot 9$ & $2 \cdot 6$ \\
\hline \multirow[t]{2}{*}{ Alternating protein: } & $120 \mathrm{~g} / \mathrm{kg}$ & $125 \cdot 8$ & $15 \cdot 7$ & $147 \cdot 3$ & $14 \cdot 5$ \\
\hline & $300 \mathrm{~g} / \mathrm{kg}$ & $89 \cdot 3$ & $7 \cdot 7^{\mathrm{a}}$ & $78 \cdot 2$ & $10 \cdot 3$ \\
\hline \multicolumn{6}{|l|}{$\mu \mathrm{mol} / \mathrm{kg}$ body-wt: } \\
\hline Control & & $3320 \cdot 0$ & $250 \cdot 0$ & $3320 \cdot 0$ & $250 \cdot 0$ \\
\hline \multirow[t]{2}{*}{ Intermittent feeding: } & Fed $1 \mathrm{~d}$ & $2800 \cdot 0^{\mathrm{a}}$ & $180 \cdot 0$ & $4150 \cdot 0^{b}$ & $310 \cdot 0$ \\
\hline & Fasted $1 \mathrm{~d}$ & $340 \cdot 0^{\mathrm{a} *}$ & $180 \cdot 0$ & $380 \cdot 0^{\mathrm{a} *}$ & $50 \cdot 0$ \\
\hline \multirow[t]{2}{*}{ Alternating protein: } & $120 \mathrm{~g} / \mathrm{kg}$ & $3330 \cdot 0^{a}$ & $420 \cdot 0$ & $3610 \cdot 0^{a}$ & $360 \cdot 0$ \\
\hline & $300 \mathrm{~g} / \mathrm{kg}$ & $2070 \cdot 0^{\mathrm{a} *}$ & $180 \cdot 0$ & $1730 \cdot 0^{\mathrm{a} *}$ & $230 \cdot 0$ \\
\hline
\end{tabular}

a.b Values within a horizontal row with unlike superscript letters were significantly different $(P<0 \cdot 05)$.

* Mean values were significantly different from control values $(P<0.05)$.

$\dagger$ Chickens (7-d-old; average wt $160 \mathrm{~g}$ ) were assigned to these dietary treatments : (1) control $(210 \mathrm{~g} \mathrm{protein} / \mathrm{kg}$ diet for the entire experimental period), (2) intermittent feeding ( $210 \mathrm{~g}$ protein $/ \mathrm{kg}$ diet for $1 \mathrm{~d}$ followed by a $1 \mathrm{~d}$ fast) or (3) a daily alternating dietary protein regimen $(120 \mathrm{~g} / \mathrm{kg}$ protein on day 1 and $300 \mathrm{~g} / \mathrm{kg}$ protein on day 2). These cycles were continued for $20 \mathrm{~d}$ and then chickens were selected from each treatment to determine the effects of dietary treatments on intermediary metabolism.

$\ddagger$ Pens of controls were subjected to a single intermittent feeding or alternating protein feeding.

$(P<0.05)$ glucose production compared with the control diet. Compared with the control diet, a single intermittent feeding regimen also decreased $(P<0.05)$ glucose production following fasting and restored production following the refeeding phase. A comparison between chronic and acute treatment groups showed a lower rate of glucose production following the refeeding of the chronic than of the acute treatment group. Switching from 300 to $120 \mathrm{~g}$ protein $/ \mathrm{kg}$ diet also decreased $(P<0.05)$ glucose production in the acute group. The absolute values were similar for both treatment groups following this period of treatment.

Compared with values for controls, the $1 \mathrm{~d}$ fast decreased $(P<0.05)$ plasma insulin in chickens; however, refeeding these same chickens increased $(P<0.05)$ insulin $300 \%$ relative to controls (Table 7). A single intermittent feeding regimen also gave similar results, although the magnitude of the response was not nearly as great. A comparison between chronic and acute treatment groups showed that the rebound in plasma insulin was greater $(P<0.05)$ in the chronic than in the acute treatment group.

When compared with values for controls, the $1 \mathrm{~d}$ refeed increased $(P<0.05)$ plasma $\mathrm{T}_{3}$ and decreased $(P<0.05)$ plasma $\mathrm{T}_{4}$ in chickens. We also noted the same trend when chickens were switched from a diet containing $300 \mathrm{~g}$ protein $/ \mathrm{kg}$ to one containing $120 \mathrm{~g}$ protein $/ \mathrm{kg}$.

In the context of this experiment (altered feeding behaviour in all treatment groups compared with the ad lib.-feeding regimen), we found that an increase in protein intake decreased $(P<0.05)$ both ME and FAS activities (Table 8$)$. The higher protein intake and fasting increased ICD activity and the higher energy intake increased FAS activity. 
Table 7. Expt 2. Effect of intermittent feeding ( $1 d$ fast-1 $d$ refeed) or alternating protein feeding (120 g protein $/ \mathrm{kg}$ on day 1 and $300 \mathrm{~g}$ protein $/ \mathrm{kg}$ on day 2) regimens on certain metabolic hormone concentrations $(\mathrm{ng} / \mathrm{ml})$ in chickens $\dagger$

(Mean values with their standard errors for four pens per dietary treatment)

\begin{tabular}{|c|c|c|c|c|c|}
\hline & & \multicolumn{2}{|c|}{ Cycled days $7-28 \dagger$} & \multicolumn{2}{|c|}{ Control days 7-28t } \\
\hline & & Mean & $\mathbf{S E}$ & Mean & SE \\
\hline \multicolumn{6}{|l|}{ Insulin: } \\
\hline Control & & 0.56 & 0.04 & 0.56 & 0.04 \\
\hline Intermittent feeding: & $\begin{array}{l}\text { Fed } 1 \mathrm{~d} \\
\text { Fasted } 1 \mathrm{~d}\end{array}$ & $\begin{array}{l}1 \cdot 84^{\mathrm{a} *} \\
\text { nd }\end{array}$ & $0 \cdot 16$ & $\begin{array}{c}0.60^{\mathrm{h}} \\
\text { nd }\end{array}$ & 0.03 \\
\hline \multirow[t]{2}{*}{ Alternating protein: } & $120 \mathrm{~g} / \mathrm{kg}$ & $0.47^{\mathrm{a}}$ & 0.03 & $0 \cdot 39^{a}$ & 0.03 \\
\hline & $300 \mathrm{~g} / \mathrm{kg}$ & $0.82^{\mathrm{a} *}$ & 0.01 & $0 \cdot 22^{\mathrm{b} *}$ & 0.02 \\
\hline \multicolumn{6}{|l|}{ Triiodothyronine: } \\
\hline Control & & $5 \cdot 08$ & $0 \cdot 26$ & $5 \cdot 08$ & 0.26 \\
\hline \multirow[t]{2}{*}{ Intermittent feeding: } & Fed $1 \mathrm{~d}$ & $6 \cdot 41^{8 *}$ & $0 \cdot 38$ & $4 \cdot 11^{b *}$ & 0.20 \\
\hline & Fasted $1 \mathrm{~d}$ & $4.53^{\mathrm{a}}$ & $0 \cdot 31$ & $4 \cdot 63^{a}$ & 0.20 \\
\hline \multirow[t]{2}{*}{ Alternating protein: } & $120 \mathrm{~g} / \mathrm{kg}$ & $7 \cdot 35^{\mathrm{a} *}$ & 0.27 & $7 \cdot 33^{2 *}$ & 0.42 \\
\hline & $300 \mathrm{~g} / \mathrm{kg}$ & $5 \cdot 28^{2}$ & $0 \cdot 17$ & $6 \cdot 40^{2 *}$ & $0 \cdot 38$ \\
\hline \multicolumn{6}{|l|}{ Thyroxine } \\
\hline Control & & $7 \cdot 45$ & $0 \cdot 27$ & $7 \cdot 45$ & $0 \cdot 27$ \\
\hline \multirow[t]{2}{*}{ Intermittent feeding: } & Fed $1 \mathrm{~d}$ & $6 \cdot 45^{\mathrm{a}}$ & 0.49 & $8 \cdot 14^{a}$ & $0 \cdot 25$ \\
\hline & Fasted $1 \mathrm{~d}$ & $12 \cdot 03^{\mathrm{a} *}$ & 0.59 & $11 \cdot 14^{\mathrm{a} *}$ & $0 \cdot 39$ \\
\hline \multirow[t]{2}{*}{ Alternating protein: } & $120 \mathrm{~g} / \mathrm{kg}$ & $4 \cdot 70^{\mathrm{a} *}$ & $0 \cdot 38$ & $5 \cdot 45^{a *}$ & $0 \cdot 30$ \\
\hline & $300 \mathrm{~g} / \mathrm{kg}$ & $8 \cdot 71^{\mathrm{a}}$ & $0 \cdot 38$ & $9 \cdot 50^{\mathrm{a} *}$ & $0 \cdot 31$ \\
\hline
\end{tabular}

nd, Not determined.

a.b Values within a horizontal row with unlike superscript letters were significantly different $(P<0.05)$.

* Mean values were significantly different from control values $(P<0.05)$.

$\uparrow$ Chickens (7-d-old; average wt $160 \mathrm{~g}$ ) were assigned to these dietary treatments: (1) control (210 g protein/ $\mathrm{kg}$ diet for the entire experimental period), (2) intermittent feeding $(210 \mathrm{~g}$ protein $/ \mathrm{kg}$ diet for $1 \mathrm{~d}$ followed by a $1 \mathrm{~d}$ fast) or (3) a daily alternating dietary protein regimen $(120 \mathrm{~g}$ protein $/ \mathrm{kg}$ on day 1 and $300 \mathrm{~g}$ protein $/ \mathrm{kg}$ on day 2). These cycles were continued for $20 \mathrm{~d}$ and then chickens were selected from each treatment to determine the effects of dietary treatments on intermediary metabolism.

$\ddagger$ Pens of controls were subjected to a single intermittent feeding or alternating protein feeding.

\section{DISCUSSION}

Interpreting results of experiments using rodents and extrapolating these results to explain regulation of lipogenesis in chickens is difficult. The liver is the major site of lipogenesis in chickens and only a minor site in young rodents. In addition, the usual method of testing the effect of dietary protein on metabolism involves changing the maize:soya-bean meal value which also alters the carbohydrate content of the diet. We feel that by maintaining a constant quantity of carbohydrate in the diet, we can attribute results to changes in protein intake.

Rats fed on an intermittent basis demonstrate many of the characteristics of meal-fed animals (Leveille, 1970). The switch from a high- to a low-protein diet and from a fasted to a fed state rapidly increased lipogenesis in a fashion similar to the meal-feeding response seen in rodents. The present study indicates that this increase is also greater when chickens are repeatedly fasted and refed or fed alternating high-low-protein diets. Yeh \& Leveille (1971) and Tanaka et al. (1983) reported similar findings in older chickens. The former group attributed the rapid change to a decrease in fatty acid release from adipose tissue during changes from low to high lipogenic states. This decrease increases CoA availability for the citrate cleavage and acetyl-CoA carboxylase $(E C 6.4 .1 .2)$ reactions. In 
Table 8. Expt 2. Effect of intermittent feeding ( $1 d$ fast $-1 d$ refeed) or alternating protein feeding ( $120 \mathrm{~g}$ protein $/ \mathrm{kg}$ on day 1 and $300 \mathrm{~g}$ protein $/ \mathrm{kg}$ on day 2) regimens on certain liver enzyme activities (one unit is that amount of enzyme resulting in the production of $1 \mu \mathrm{mol}$ oxidized or reduced $N A D P /$ min at $25^{\circ}$ ) in broiler chickens $\dagger$

(Mean values with their standard errors for four pens per dietary treatment)

\begin{tabular}{|c|c|c|c|c|c|c|c|c|c|c|c|c|}
\hline \multirow[t]{3}{*}{ Enzyme... } & \multicolumn{4}{|c|}{ FAS } & \multicolumn{4}{|c|}{ ME } & \multicolumn{4}{|c|}{ ICD } \\
\hline & \multicolumn{2}{|c|}{$\begin{array}{c}\text { Cycled } † \\
\text { days } 7-28\end{array}$} & \multicolumn{2}{|c|}{$\begin{array}{c}\text { Control }+ \\
\text { days } 7-28\end{array}$} & \multicolumn{2}{|c|}{$\begin{array}{c}\text { Cycled } \dagger \\
\text { days } 7-28\end{array}$} & \multicolumn{2}{|c|}{$\begin{array}{c}\text { Control } \ddagger \\
\text { days } 7-28\end{array}$} & \multicolumn{2}{|c|}{$\begin{array}{c}\text { Cycled } \dagger \\
\text { days } 7-28\end{array}$} & \multicolumn{2}{|c|}{$\begin{array}{c}\text { Control } \ddagger \\
\text { days } 7-28\end{array}$} \\
\hline & Mean & SE & Mean & SE & Mean & SE & Mean & $\mathrm{SE}$ & Mean & SE & Mean & SE \\
\hline \multicolumn{13}{|l|}{ Units/g liver: } \\
\hline Control & $0-8$ & 0.1 & $0 \cdot 8$ & $0 \cdot 1$ & $2 \cdot 6$ & 0.2 & $2 \cdot 6$ & $0 \cdot 2$ & 23.9 & $1 \cdot 2$ & $23 \cdot 9$ & $1 \cdot 2$ \\
\hline Intermittent feeding:Fed $1 \mathrm{~d}$ & $1 \cdot 4^{\mathrm{a} *}$ & $0 \cdot 1$ & $1 \cdot 8^{\mathrm{b} *}$ & $0 \cdot 1$ & $3 \cdot 4^{\mathrm{a}}$ & 0.6 & $9 \cdot 1^{b *}$ & 1.5 & $23 \cdot 5^{\mathrm{a}}$ & 0.8 & $26 \cdot 5$ & $1 \cdot 1$ \\
\hline Fasted $1 \mathrm{~d}$ & $1 \cdot 0^{\mathrm{a}}$ & $0 \cdot 1$ & $0 \cdot 9^{\mathrm{a}}$ & $0 \cdot 1$ & $0 \cdot 9^{a *}$ & $0 \cdot 1$ & $3 \cdot 5^{\mathrm{b}}$ & 0.5 & $37 \cdot 4^{\mathrm{a}}$ & $1 \cdot 4$ & $45 \cdot 3^{b *}$ & 1.8 \\
\hline Alternating protein : $120 \mathrm{~g} / \mathrm{kg}$ & $2 \cdot 1^{1 *}$ & $0 \cdot 2$ & $2 \cdot 2^{\mathrm{a} *}$ & $0 \cdot 1$ & $6 \cdot 1^{a *}$ & $0 \cdot 2$ & $7 \cdot 4^{\mathrm{b} *}$ & 0.7 & $20 \cdot 6^{a}$ & 1.0 & $22 \cdot 5$ & 0.9 \\
\hline $300 \mathrm{~g} / \mathrm{kg}$ & $0 \cdot 8^{\mathrm{a}}$ & $0 \cdot 1$ & $1 \cdot 1^{\mathrm{a}}$ & 0.6 & $6 \cdot 6^{a *}$ & 0.6 & $7 \cdot 2^{\mathrm{a} *}$ & $0 \cdot 2$ & $27 \cdot 3^{\mathrm{a}}$ & $2 \cdot 5$ & $28 \cdot 1 *$ & 0.9 \\
\hline \multicolumn{13}{|l|}{ Units/kg body-wt: } \\
\hline Control & $18 \cdot 0$ & $1 \cdot 1$ & 18.0 & $1 \cdot 1$ & $56 \cdot 0$ & $5 \cdot 5$ & $56 \cdot 8$ & $5 \cdot 5$ & $510 \cdot 0$ & 23.0 & 510.0 & $23 \cdot 0$ \\
\hline Intermittent feeding:Fed $1 \mathrm{~d}$ & $34 \cdot 0^{2 *}$ & 40 & $44 \cdot 0^{\mathrm{b} *}$ & $3 \cdot 3$ & $82 \cdot 0^{\mathrm{a}}$ & $12 \cdot 0$ & $216 \cdot 0^{\mathrm{b} *}$ & $36 \cdot 0$ & $556 \cdot 0$ & $9 \cdot 1$ & $625 \cdot 0^{*}$ & $26 \cdot 0$ \\
\hline Fasted ld & $22 \cdot 0^{\mathrm{a}}$ & $1 \cdot 1$ & $21 \cdot 0^{\mathrm{a}}$ & $3 \cdot 3$ & $19 \cdot 0^{\mathrm{a} *}$ & $1 \cdot 1$ & $74 \cdot 0^{\mathrm{D}}$ & $10 \cdot 0$ & $815 \cdot 0^{\mathrm{a} *}$ & $30 \cdot 0$ & $947 \cdot 5^{b *}$ & $38 \cdot 0$ \\
\hline Alternating protein: $120 \mathrm{~g} / \mathrm{kg}$ & $55 \cdot 0^{2 *}$ & $4 \cdot 4$ & $52 \cdot 0^{\mathrm{a}}$ & $2 \cdot 2$ & $160 \cdot 0^{\mathrm{a} *}$ & $24 \cdot 0$ & $171 \cdot 0^{\mathrm{a} *}$ & $17 \cdot 0$ & $544 \cdot 0^{a}$ & $18 \cdot 0$ & $515 \cdot 0$ & $21 \cdot 0$ \\
\hline $300 \mathrm{~g} / \mathrm{kg}$ & $19 \cdot 0^{\mathrm{a}}$ & $2 \cdot 2$ & $25 \cdot 9^{\mathrm{a}}$ & $3 \cdot 3$ & $149 \cdot 0^{2 *}$ & $24 \cdot 0$ & $166 \cdot 3^{a *}$ & 6.0 & $622 \cdot 0^{2 *}$ & $56 \cdot 0$ & $646 \cdot 0^{*}$ & $2 \mathrm{I} \cdot 0$ \\
\hline
\end{tabular}

FAS, fatty acid synthase ( $E C$ 2.3.1.85); $\mathrm{ME}$, malate dehydrogenase (oxaloacetate-decarboxylating) $\left(\mathrm{NADP}^{+}\right)$ (malic enzyme) (EC 1.1.1.40); ICD, isocitrate dehydrogenase (NADP $\left.{ }^{+}\right)(E C$ 1.1.1.42)

a,b Values within a horizontal row with unlike superscript letters were significantly different $(P<0.05)$.

* Mean values were significantly different from control values $(P<0.05)$.

$\dagger$ Chickens (7-d-old; average wt $160 \mathrm{~g}$ ) were assigned to these dietary treatments: (1) control (210 $\mathrm{g} \mathrm{protein} / \mathrm{kg}$ diet for the entire experimental period), (2) intermittent feeding ( $210 \mathrm{~g}$ protein $/ \mathrm{kg}$ diet for $1 \mathrm{~d}$ followed by a $1 \mathrm{~d}$ fast) or (3) a daily alternating dietary protein regimen $(120 \mathrm{~g}$ protein $/ \mathrm{kg}$ on day 1 and $300 \mathrm{~g}$ protein $/ \mathrm{kg}$ on day 2). These cycles were continued for $20 \mathrm{~d}$ and then chickens were selected from each treatment to determine the effects of dietary treatments on intermediary metabolism.

$\ddagger$ Pens of controls were subjected to a single intermittent feeding or alternating protein feeding.

contrast, Tanaka et al. (1983) wrote that the supply of reducing equivalents (NADPH) regulates lipogenesis de novo in chickens. Based on a noted high correlation between ME activity and lipogenesis de novo, Yeh \& Leveille (1969) originally proposed that availability of NADPH regulates lipid metabolism in chickens fed on high-protein diets.

The enzyme activities in the present study indicate that ICD functions in both lipid and protein metabolism. The enzyme provides both a residual capacity for the production of reducing equivalents and a co-reactant for transamination ( $\alpha$-ketoglutarate). Competition exists between acetyl-CoA carboxylase and the aconitase-isocitrate dehydrogenase pathway for limited cytoplasmic citrate. Thus, the requirement for $\alpha$-ketoglutarate as a coreactant for transamination of excess amino acids depresses citrate levels and the subsequent activation of acetyl CoA carboxylase. Phosphorylation-dephosphorylation did not control avian acetyl-CoA carboxylase to the extent noted in the rat enzyme. Thus, citrate levels appear to control the avian enzyme more than the rat enzyme (Clark et al. 1979). Hillard et al. (1980) reported that dietary carbohydrate was a potent regulator of avian lipogenesis, possibly through a regulation of the supply of citrate.

Oppenheimer et al. (1978) found a positive correlation between $T_{3}$ level and hormone action at the cellular level. According to their hypothesis, a decrease in either tissue binding or circulating levels of $T_{3}$ (as is the case in the present study) would decrease enzyme 
activity. Although ME may provide the necessary NADPH for lipogenesis, findings from the present study do not necessarily show that the enzyme strictly regulates lipogenesis.

The increase in serum insulin accompanying an increase in dietary protein suggests a different method of insulin regulation in chickens than in mammals. Amino acids, rather than glucose, are the major stimuli for insulin release from the islet cells in teleosts (Ablett et al. 1983). Ablett et al. (1983) suggested that high-protein diets chronically elevate insulin in salmon (Salmo gairdneri) and reduce insulin binding by liver and muscle membranes. The down regulation of the insulin receptor by elevated circulating insulin is similar to the response in mammals. It is possible that tests of insulin sensitivity in birds may also require the consideration of the dietary protein level or the availability of certain amino acids.

Two experiments were conducted to compare the effects of repeated cycles of either an alternating low-high-protein or intermittent feeding regimen. Both regimens gave the familiar meal-feeding response. Repeated cycles of either of these regimens gave responses greater than a single cycle. The findings in the present study further reinforce our hypothesis that dietary protein alters lipid metabolism. Dietary carbohydrate does not support a high rate of lipogenesis when combined with a high-protein intake. Although high-protein diets result in a pattern of lipogenesis in vitro similar to fasting, hormone levels are different from fasting values.

\section{REFERENCES}

Ablett, R. F., Taylor, M. J. \& Selivonchick, D. F. (1983). The effect of high-protein and high-carbohydrate diets on $\left[{ }^{125}\right.$ I]iodoinsulin binding in skeletal muscle plasma membranes and isolated hepatocytes of rainbow trout (Salmo gairdneri). British Journal of Nutrition 50, 129-139.

Clark, S. D., Watkins, P. A. \& Lane, M. D. (1979). Acute control of fatty acid synthesis by cyclic AMP in the chick liver cell: possible site of inhibition of citrate formation. Journal of Lipid Research 20, 974-985.

Cleland, W. W., Thompson, V. M. \& Barden, R. E. (1969). Isocitrate dehydrogenase (TPN specific) from pig heart. In Methods in Enzymology, vol. 13, pp. 30-33 [J. M. Lowenstein, editor]. New York: Academic Press.

Folch, J., Lees, M. \& Sloane-Stanley, G. H. (1957). A simple method for the isolation and purification of total lipids from animal tissues. Journal of Biological Chemistry 226, 497-509.

Hanks, J. H. \& Wallace, R. E. (1949). Relation of oxygen and temperature in the preservation of tissues by refrigeration. Proceedings of the Society of Experimental Biology and Medicine 71, 196-200.

Hillard, B. L., Lundin, P. \& Clarke, S. D. (1980). Essentiality of dietary carbohydrate for maintenance of liver lipogenesis in the chick. Journal of Nutrition 110, 1533-1542.

Hsu, R. Y. \& Lardy, H. A. (1969). Malic enzyme. In Methods in Enzymology, vol. 13, pp. 230-235 [J. M. Lowenstein, editor]. New York: Academic Press.

Leveille, G. A. (1966). Glycogen metabolism in meal-fed rats and chicks and the time sequence of lipogenic and enzymatic adaptive changes. Journal of Nutrition 90, $449-460$.

Leveille, G. A. (1970). Adipose tissue metabolism: influence of periodicity of eating and diet composition. Federation Proceedings 29, 1294-1299.

Leveille, G. A. \& Yeh, Y. Y. (1972). Influence of intermittent feeding or protein-feeding on lipid metabolism in young cockerels. Journal of Nutrition 102, 733-740.

McMurtry, J. P., Rosebrough, R. W. \& Steele, N. C. (1983). A homologous radioimmunoassay for chicken insulin. Poultry Science 62, 697-701.

Mersmann, H. J., Houk, J. M., Phinney, G., Underwood, M. C. \& Brown, L. J. (1973). Lipogenesis by vitro liver and adipose tissue preparations from neonatal swine. American Journal of Physiology 224, 1123-1129.

Oppenheimer, H. H., Coulombe, P. H., Schwartz, H. \& Gutfield, N. W. (1978). Nonlinear (amplified) relationship between nuclear occupancy by triiodothyronine and the appearance rate of hepatic glycero-phosphate dehydrogenase and malic enzyme activity in the rat. Journal of Clinical Investigation 61, 987-997.

Remington, R. D. \& Schork, M. A. (1970). Statistics with Applications to the Biological and Health Sciences. Englewood Cliffs: Prentice-Hall.

Rosebrough, R. W. \& Steele, N. C. (1985). Energy and protein relations in the broiler. 1. Effect of protein levels and feeding regimes on growth, body composition and in vitro lipogenesis of broiler chicks. Poultry Science 64, $119-126$.

Stein, M. W. (1963). D-Glucose, determination with hexokinase and glucose-6-phosphate dehydrogenase. In Methods of Enzymatic Analysis, pp. 117-122 [H. U. Bergmeyer, editor]. New York: Academic Press. 
Tanaka, T., Ohtani, S. \& Shigeno, K. (1983). Effect of increasing dietary energy on hepatic lipogenesis in growing chicks. II. Increasing energy by carbohydrate supplementation. Poultry Science 62, 445-451.

Yeh, Y. Y. \& Leveille, G. A. (1969). Effect of dietary protein on hepatic lipogenesis in the growing chick, Journal of Nutrition 98, 356-366.

Yeh, Y. Y. \& Leveille, G. A. (1971). In vitro and in vivo restoration of hepatic lipogenesis in fasted chicks. Journal of Nutrition 101, 803-810. 